\title{
Humanizing the Empire and De-humanizing the Colonies: Tropicality and an Indigenous feminist rereading of British colonization and slave trade in George Colman's Inkle and Yarico(*)
}

\author{
Dr. Samia AL-Shayban \\ Associate Professor-Department of English \\ Language and Literature- \\ King Saud University-Riyadh
}

\section{Abstract}

George Colman's Inkle and Yarico, 1787, is regarded as an integral part of the eighteenth century anti-slavery literary discourse. This paper challenges the dominant critical perception of Colman's Inkle and Yarico as an anti-slavery work and re-reads it as a dramatic attempt to defend slavery and by extension colonization. Colman achieves his goal through three calculated elements: dehumanization of the Indians; humanization of the English; distancing the English from slave trade. By applying the theory of tropicality, it becomes clear that the environment and population of the West Indies emerge as inferior (Other) to those of England (Self). Indigenous feminism enables us to avoid the romantic and sentimental trap and tap into Colman's manipulation of Yarico's power as an indigenous woman. Colman employs her power to sanctify Inkle, the colonizer and the representative of imperialism as the new master of the land and its inhabitants

Key words; West Indies; England; indigenous; other; self; slavery; Barbados

${ }^{(*)}$ Bulletin of the Faculty of Arts Volume 81 Issue 4 April 2021 
ملخص:

مسرحيه جورج كولمان أنكل و ياروكي و التي عرضت في لندن للمره الأولى عام

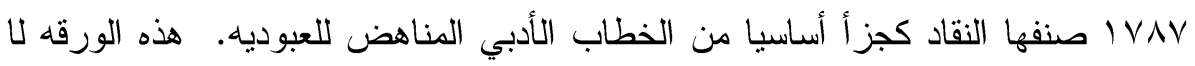

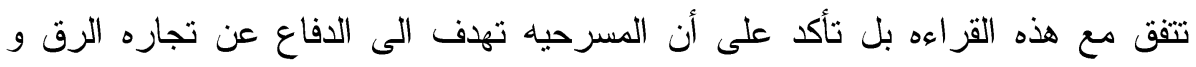
الإستعمار الذي ساعد على تقشي العبوديه. يتضح دفاع الكاتب عن تجاره الرق من خلال

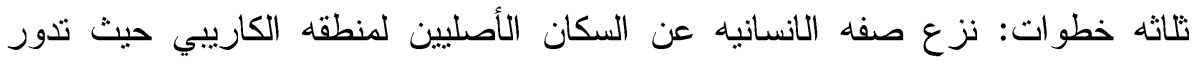
أحداث المسرحيه, إصباغ صفه الإنسانيه على المستعمرين الانجليزو نفي أبي صله بينهم و تجاره الرقيق. لإثبات ذلك يعتمد التحليل على النظريه النقديه الاستوائيه و نسويه السكان

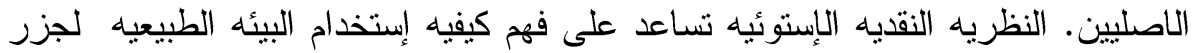
الهند الغربيه و سكانها الاصليين من أجل عرضهم كرمز للتخلف و دونيه الآخر في مقابل المستعمر الأنجليزي و الذي يعرض كرمز للحضاره و سمو مكانه الأنا. النظريه النقديه لنسويه السكان الأصليين من شأنها أن تبعدنا من فخ الوقوع فيزي في التحليل العاطفي لعلاقه

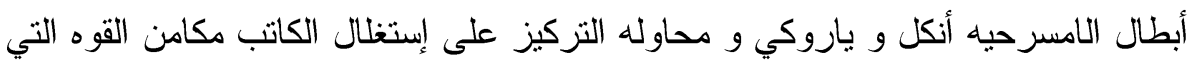

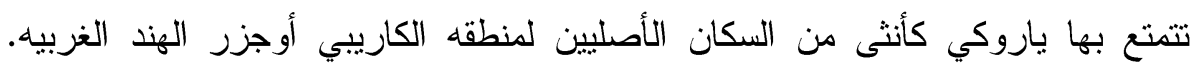

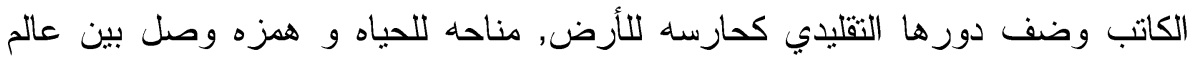

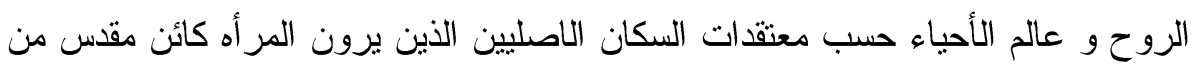
أجل تطهير المستعمر أنكل و تتصييه كسيد على الارض الكاريبيه و سكانها الاصليين. الكلمات المفتاحية :جزر الهند الغربيه, باربادوس, إنجلترا, السكان الاصليين, الآخر , الأنا, 


\section{Introduction}

Since its opening performance at Haymarket on 4 August 1787 until the end of the eighteenth century, George Colman's Inkle and Yarico, as Keith Sandiford reports, "had ... registered a total of 164 performances" $(1990,116)$. The play's numerous performances are a testimony to its appeal to the audience. The eighteenth-century dramatist, Elizabeth Inchbald, writes that Colman's play was "performed in every theatre in London and every theatre of the Kingdom with the same degree of splendid success" (1808, 20:5). The plot of this popular play is about Inkle, an English trader who is shipwrecked in the West Indies and survives with the help of a kind Indian maiden, Yarico. When he manages to reach Barbados, where he is expected to marry Narcissa, the daughter of

English governor of the island, Sir Christopher Curry, he plans to sell Yarico into slavery to recover his financial losses and marry his fiancée, who will improve his social status.

The plot is not new as it has a long history (Felsenstein 1999, 1-53; 2006, 21-35). It evolved from the French traveler, Jean Mocquet's story, which he published in Voyages to Africa, Asia, and the West and East Indies in 1617. Mocquet tells the story of an Indian woman who was deserted by her shipwrecked English lover. Disappointed, she becomes a Medea figure, kills their child and throws his parts in the sea after the departing ship (Dobie 2010, 1489). In 1657 Richard Ligon tells a similar story. The Indian woman in question is sold into slavery by her lover when pregnant. Ligon comments that poor "Yarico for her love, lost her liberty" (54-5). Ligon's plot was expanded and published by Richard Steele in the Spectator in 1711. Steel's version stresses that Yarico is sold by Inkle into slavery along with their unborn child for profit (1891, 34-7).

Being aware of the original French plot of Inkle and Yarico, along with the English versions that appeared before Colman's play, is essential to this argument. The contrast highlights the ideological significance that underlines Colman's version, where Narcissa marries another suitor and Inkle decides to stay with the non- 
pregnant Yarico instead of selling her into slavery. To Sandiford, the supposedly romantic end of the play is a reflection of the "successive generations of English audiences' positive response to the liberal ideology of the Enlightenment" (1990, 116). This liberal ideology explains the "distinctive transformational processes that were taking place

... shaping the philosophical discourse about Self and Other" (1990, 116). The most significant transformation that took place during the years of Inkle and Yarico's stage history was the anti- slavery movement. Jason Kelly explains that the anti-slavery movement falls into three phases. The expansion and resistance which lasted from 1607 to 1770 was the first phase. The third and last phase was the emancipation which took place between 1807 until 1838. What is related to this argument is the second phase, the abolition movement (1770-1807), which corresponds with Inkle and Yarico's popular period on the stage. He writes, "The second phase, from the 1770s to 1807

witnessed the rise of massive British support for the abolition of the slave trade, which many leaders believed was the first step in bringing an end to the institution of slavery". ${ }^{1}$

Felsenstein argues that the anti-slavery movement that gained momentum during the 80 s and 90 s of the eighteenth century is a determining factor in the critical readings of Colman's Inkle and Yarico. To him, the contemporary audience interpreted the play as an attack against slavery and they endorsed it as a reflection of the "liberal" values of their time $(2014,690)$. However, Felsenstein stresses that critics fail to reach an agreement regarding Inkle and Yarico's attitude toward slavery. By considering the available critical readings of slavery in Inkle and Yarico, it becomes clear that it is not a matter of disagreement but rather of different readings. The majority of critics read the play as voicing ideas of anti-slavery, others avoid the issue, while some judge it to be too ambiguous to allow for a verdict. Sandiford believes that the play's anti-slavery attitude "legitimiz[es] the history of 'other' 
voices and 'other' sensibilities" (1990, 123). Adrian Knapp argues that Colman's play advances the cause of slavery abolitionists (2012, 223-44). Mita Choudhury insists that Colman's play cannot be read as "anti- or pro-abolitionist" $(2014,696)$. She even asserts that Colman "seems to have had no interest in the ongoing debates about the "slave trade" $(2014,698)$. Jean Marsden considers Inkle as a calculating and mercenary figure $(2014,692-6)$. She believes that "for the English audience Inkle's willingness to sell Yarico represented empire at its most disturbing" (2019, 121). Marsden refrains from clarifying if the audience are disturbed by selling Yarico in particular or slavery in general. The complexity of the critical approaches used to analyze the play motivates Felsenstein to conclude that "we [will] probably never be certain of Colman's specific intention" toward slavery $(2014,690)$.

This paper argues that there are no ambiguities regarding Colman's dramatization of slavery, as claimed by Felsenstein. As such, the argument challenges the dominant critical perception of Colman's Inkle and Yarico as a work on anti-slavery, and re-reads it as a dramatic attempt to defend slavery and by extension colonization. This can be perceived through Colman's three calculated elements: dehumanization of the Indians; humanization of the English; and denying the English a key role in the transatlantic slave trade and limiting their involvement in improving the lives of their slaves. The dehumanizing and humanizing processes are manifested through a multifaceted and complex contrast between both the natural environment and the human inhabitants of England and the Caribbean island. This contrast is meant to stress the colonizers' superiority and the inferiority of the colonized.

To distance the English from the transatlantic slave trade, Colman employs three techniques. First, he allows slavery in the West Indies as a trade to emerge as an existing practice with vague roots and affiliations. This enables him to furnish the English colonizers with the technical and moral justification to 
buy slaves Second, the English as represented by Sir

Christopher Curry deny any key role in the slave trade. Third, Sir Christopher Curry justifies buying slaves on purely moral grounds. Buying slaves is motivated by the English desire to protect them and give them a better life. In this way Colman allows the English to practice slavery while not only remaining safe from criticism but being praised for buying the unfortunate slaves.

In order to expose Colman's support of slavery and colonization, this argument employs the theories of tropicality and indigenous feminism in analyzing Inkle and Yarico. The theory of tropicality discourse constructs the tropical world as the West environmental Other (Clayton and Bowd 2006, 208-9). By applying this theory, the reader or the audience can understand how the West Indies' environment and its population emerge as inferior to those of England. By staging the tropics as the Other, Colman gives the colonizers of the West Indies the needed moral justification to enslave the Indians and dominate their land. Indigenous feminism offers a fresh reading of Marico's identity as a sacred indigenous female who represents the land and the world of the spirits. Being aware of her sacred identity, we tap into Colman's manipulation of her power and love to sanctify Inkle, the colonizer and the representative of imperialism as the new master of the land and its inhabitants. For structural purposes, the paper falls into three parts, the first and second parts explore the contrast between the Caribbean island and England's environment and inhabitants. The third part examines Colman's dramatic manipulation of the role the English played in the slave trade through marginalizing the practice and turning Barbados into a colonial beacon of civilization and humanity.

\section{The Other: Tropical natural habitat and its indigenous locals}

David Lowenthal and Marlyn Bowden write that tropicality is "a geographical and political discourse" that promotes the 
"inferiority of tropical as opposed to temperate environments" (1967,

7). Felix Driver and Luciana Martins stress that "the contrast between the temperate and the tropical is one of the most enduring themes in the history of global imaginings. Whether represented positively ... or negatively ... Tropicality has frequently served as a foil to temper ate nature, to all that is modest, civilized, cultivated" $(2005,3)$. With the help of tropical theory, one finds that Colman composes a dramatic discourse that creates binaries between racialized (Caribbean island) and normative (England/colonized Barbados) geographical spaces, along with their human inhabitants. The contrast shows that the geographical space of the Caribbean island which is occupied by barbaric savages is intemperate and dangerous. On the other side stand England and Barbados with their temperate environments and civilized inhabitants. Significantly, the natural environment of the island is introduced through a multifaceted negative image by Medium, an English shipwrecked merchant. He labels the unnamed island as "Wilds of America" (1807, 1. 1). Keeping the island unidentified allows its characteristics to represent all the tropical islands and their inhabitants. The image of wilderness is highly negative, loaded with dangerous connotations. This initial negative impression of the island is stressed through the inability to communicate. Medium, who is searching for his missing nephew Inkle, tells his companion, Trudge, "Pshaw! It's only wasting time and breath. Bawling won't persuade him to budge a bit faster. Things are all alter'd now; and whatever weight it may have in some places, bawling it seems, don't go for argument here" (1.1). Medium is talking about his nephew, Inkle, who fails to show himself or respond to his servant's shouts. He states that they are in a geographical location where the conventional forms of communication do not apply. In the wilds of America, neither calls nor argument can be of use. It is significant to note that Medium speaks with authority about a geographical space he never visited before. However, his attitude toward the tropics is typical of his time. His authoritative judgment is the result of 
his position as the powerful colonial Self, informing us about the inferior other, the tropics (Arnold 2000, 9-10). He simply conveys partial knowledge and ideas "that, since the fifteenth century, has both created and been shaped by distinction between temperate and tropical land" (Clayton and Bowd 2006, 209).

The absence of any mechanism to trace those who go missing gives the island a foreboding atmosphere. Medium declares that "there is something in the air of the forest, I believe, that inclines people to be hasty" (1.1). Such inclination is the result of the predators like "lions ... jackals ... crocodiles ... and baboons" that are supposed to roam the island (1.1). This is a typical tropical discourse of the intemperate natural landscape of the tropics, where "the ferocity of tigers and other carnivorous beasts" roam the forests and turn it into a dangerous place (Arnold 2000, 8; De Oviedo 1959, 37). The presence of the dangerous animals that roam the island is confirmed by Yarico, who informs Inkle, "Our woods are filled with beasts of prey" (1.1). By allowing the indigenous Yarico to confirm the dangerous natural environment of her island, Colman, the colonizer, confirms the primitive and regressive environment of the island while maintaining an impartial position.

After establishing the dangerous and primitive natural environment of the tropical island, Colman introduces its human inhabitants. Arnold clarifies that in tropical discourse "the perception of primitiveness in nature inevitably extended to the human inhabitants ... as well" $(2000,11)$. Significantly, both men and women of the tropical island are presented as less than human. However, it should be noted that Colman follows complex and multifaceted techniques in dehumanizing the indigenous males and females. He assigns men specific racial traits: they are black, violent in nature and cannibalistic. In addition, he denies them agency. Before encountering the inhabitants, Medium asserts that they are black in color. He tells Trudge that Inkle has left the ship to the island, "when he knows every inhabitant here is ... as 
black as a pepper-corn" (1.1). In this context, it is obvious that Medium invokes a black and white binary. Medium makes it clear that the locals' black color is enough as a factor to forbid any form of communication with them. The black color of the indigenous inhabitants of the island assumes a sinister dimension through considering them as a curse. Medium tells Inkle that the island is "cursedly, incumbered with black legs" (1.1). This explains that the remark about blackness goes beyond the skin color of the local inhabitants of the island and points to them as the inferior Other. Roxann Wheeler remarks that the color issue is "a dense matrix of ideas as closely associated with cultural differences as with the body's surface" $(2000,2)$. Wheeler remarks that during the eighteenth century skin color was a dominant issue. It was a matter of cultural identity that separated the superior whites from the inferior blacks (Young 1995, 6).

James Walvin explains that black skin color and slavery were inseparable. Slavery in the "New World became ethnically defined. To be a slave was to be black; and to be black, it was assumed, meant being a slave. The converse was also true. To be white was to be free" $(2013,12)$. The color issue took a more inhuman twist as it was debated whether blacks were humans or part of the animal-kingdom. This shocking debate was a serious issue that gained support from science (Young 1995, 6-7). Edward Long, who was a slave owner, associates black color with inferiority. He writes, "For my own part, I think there are extremely potent reasons for believing, that the White and the Negroes are two distinct species" (1774, 336). Long's opinion is particularly important it was highly popular (Young 1995, 8). The popularity was evident from the systematic and institutionalized inhuman treatment slaves and blacks were subjected to. By the time Colman staged his play "skin color emerges as the most important component of racial identity in Britain" (Wheeler 2000, 9). It is logical that such emergence cannot be disconnected from the fact that during the same period, "race and colonialism, as well as race and slavery, became intimately codependent" (Wheeler 2000, 9). Since black was 
the color associated with slaves who were an essential commodity in the economy of the expanding British Empire, Colman's audience must have been aware of the negative connotation generated by the color message.

Conventionally, negative presentation of the tropics is "centered on images of ...violence" and Colman follows the tradition faithfully (Livingstone 1991, 8). Before meeting the natives, Medium confirms their violent nature: "we shall be stript and plunder' $d$ in a minute" (1.1). The terrified Trudge endorses the violent nature of the natives, by saying "We shall all be put to the sword by the knives of the natives; I'm told they take off heads like hats, and hang 'em on pegs in their parlours" (1.1). Trudge projects a picture of violence which has been conventionally circled for centuries. De Oviedo clarifies that a powerful negative image of the tropics' inhabitants is centered on destruction, violence and primitiveness $(1959,37)$. The natives' violence is directed not only toward humans but animals as well. Trudge tells his master, "if we once get clear of the Natives houses, we have little to fear from the lions and leopards; for by the appearance of their parlours they seem to have kill'd all the wild beasts in the country" (1.1). To confirm the natives' violent nature, Colman enlists one of them to endorse such an opinion. Yarico warns Inkle, "do you know the danger that surrounds you here? ... my country-men ... might kill you" (1.1). Unable to understand the factors behind his presence in such an alien geographic location, Medium wonders, "what harm did I ever do to be hunted to death by a pack of black bloodhounds?" (1.1). Black bloodhounds in particular are extremely violent and skilled hunters. This image of extreme savagery pushes the indigenous males outside human nature to be animal-like.

The natives' violence takes another dimension and evolves into cannibalism. When Inkle informs his uncle that he considers catching a few native men to sell them as slaves, Medium labels him "young Cannibal Catcher" (1.1). Medium reminds his nephew of the grave consequences of delaying their sail toward 
Barbados. He warns him "Who knows but instead of sailing to a wedding, we may get Cut up here for a wedding dinner, toss'd up for a dingy duke Perhaps, or stew'd down for a black baronet, or eat raw by an Inky commoner?" (1.1). Obviously, Medium fails to express any moral reservations toward slavery. His objection to enslaving the natives is purely pragmatic and not moral. They simply do not have the time as Inkle is supposed to reach Barbados to wed the daughter of the governor, Sir Christopher Curry. Failing to leave the island as soon as possible means that they will be eaten alive or dead by the natives. Deliberately, Colman allows his English characters to be in a matter of life or death confrontation with the black cannibals. In such a context, enslaving them is an acceptable moral choice. The cannibalistic nature of the island's men is confirmed by the native female Wowski, Yarico's maid and companion. She informs Trudge of the tragic end of an English captain who landed on their island. When Trudge asks, "What did your countrymen do for the poor fellow?" she responds, "Eat him one day. Our chief kill him" (1.1). In his well- known travel book, Jean Mocquet describes the Caribs as "Man-Eaters." He tells a story of "an Indian woman offered a roasted Hand to our General, but he angrily refused it" (1696, 78-80). Felsenstein defends the Caribbean people against cannibalism. He writes, "recent inquiry has demonstrated that the case for the historical existence of cannibalism as an omnipresent rite among the Caribs let alone many other 'primitive' people is far from proved" (1999, 5). Stephen Greenblatt believes that the "Europeans had long identified cannibalism as an emblem of horror" $(1991,136)$. In our context, cannibalism is meant to stress the non-human and savage nature of the native islanders.

To confirm the non-human status of the indigenous men, Colman denies them autonomy and agency. To that end, Colman dramatizes them as faceless, nameless and voiceless. At no point throughout the play are we directly introduced to the indigenous males of the island. Such an absence does not simply mark them as inferior, but most importantly, denies them an existence as human 
beings. Denying the male population of the island agency is an essential step to avoid the moral implications of enslaving them. By denying them agency, Colman can screen the indigenous people's resistance to the colonizers. Such resistance undermines slavery not only from a moral perspective but also from a legal stand. Historically, indigenous men tend to be freedom fighters and leaders of rebellions. The Caribbean islands witnessed various and serious armed conflicts between indigenous populations and slaves on one hand and colonizers on the other (Higginson 2005, 4-72; Matthews 2006, 1-2; Clarke 1972, 117). Clarke argues that the Europeans tended to deny their slaves, "culture ... [and] humanity" (1972, 117). Understandably, by denying their slaves culture and humanity, the Europeans denied them agency and autonomy and by extension the right to resist. Clarke clarifies the relationship between culture and autonomy. He argues the native culture of the slaves was a key factor in the "success of a large number of the slave revolts in the Caribbean islands" $(1972,117)$. Prithi Kanakamedala points that Georgian theatre, which was known for staging plays about slaves, tended to overlook the indigenous men's culture and role in resisting the European colonizers $(2014,674)$. She elaborates that dramatists from the era manipulated historical realities and failed to stage the inhuman treatment the indigenous men suffered at the hands of the colonizers, from the middle passage to their work on the plantations (2014, 674; Brown 2017, 1-12; Walvin 2013, 13). Kanakamedala is keen to draw attention to the fact that the popularity of slavery on the eighteenth-century stage does not necessarily indicate moral commitment but rather profitable entertainment. In most cases, theatre managers were business men committed to profits and not the anti-slavery movement. She concludes that the slave "was commoditized to ensure the commercial vibrancy of the theatrical market" $(2014,673)$. By considering the general mode of the eighteenth century of staging slavery, it is not difficult to place Colman's dramatic manipulation of slavery outside the emancipation practice. One can see that Colman is working hard to prevent his audience from sympathizing 
with the black inhabitants of the island and consequently condemn slavery. Colman's insistence to deny the indigenous population agency is an essential step to deny them culture. In its turn the denial of culture means the denial of autonomy and all the moral values that come with it. Consequently, the indigenous males emerge as mere savages who are incapable of displaying the noble spirit that generates reverence for freedom and rejection of the British hegemony.

\section{Yarico: Colonial image of the indigenous female}

Significantly, like her male countrymen, Yarico is denied cultural identity and therefore humanity. To Colman, the dehumanizing process of Yarico is a key element to her subsequent multileveled exploitation as an indigenous woman. Before looking into Yarico's dehumanizing process, it is essential to consider the critical consensus of her character. Critics believe that Yarico receives sympathetic dramatization. Felsenstein argues that through Yarico's forgiveness of Inkle at the end of the play, Colman intends "to enhance [the] nobility ... of her feeling heart" $(2006,26)$.

O'Quinn believes that Yarico's sympathetic dramatization "was mobilized in condemnation of Inkle's mercantile greed" (2002, 389). With the help of indigenous feminism, this argument challenges this perception and points out that like her male counterparts, Yarico has been dehumanized. The choice of this critical theory is motivated by the fact that it "engages the crucial issues of cultural identity ... particular to the indigenous context and its female population" (Huhndorf and Suzack 2010, 2). Furthermore, indigenous feminism will help in going beyond the simple romantic façade of the love story and analyze how colonialism operates beneath layers of claimed superiority to possess the land and its inhabitants.

Kim Anderson explains that indigenous women lived in a context where they enjoyed a considerable amount of power unattained by the European women, who lived in patriarchal societies. Indigenous culture "promoted womanhood as a sacred 
identity that existed within a complex system of relations of societies that were based on balance" (2000, 57). Their communities granted them such power as Anderson confirms, "Women were recognized for their unique contributions in the lifegiving process. Indigenous creation stories taught that all life was born of the female, and indigenous ceremonies replicated the cycles of renewal and rebirth that femininity represented" $(2011,82)$. The other element we need to keep in mind is that indigenous women occupy a sacred position in their communities as the representatives of earth. (Anderson 2000, 71; Saidero 2017, 263). Being able to "bring new life into the world, women play an intermediary role between life on earth and in the spirit world" (Anderson 2000, 72). Significantly, Colman chooses to screen the sacred and powerful identity of indigenous women in dramatizing Yarico, who emerges as a voiceless and rootless body. Yarico's absent voice is stressed through her relationship with Inkle, the English colonizer. Yarico spends her initial appearance on the stage adulating Inkle. Upon seeing Inkle in her cave, she swoons "Ah? What form is this? Are you man?" (1.1). Marico's question is meant to stress Inkle's striking masculine beauty. She wonders, "What a shape; How fair his skin too" (1.1). It turns out that Inkle's voice is no less charming than his looks. When he confirms that he is indeed a mortal, Yarico wonders, "what harmony in his voice" (1.1). Yarico reaches the conclusion that Inkle is a superior male figure whose masculine beauty and fair skin distinguish him from the indigenous black men running around the island. According to the tropical discourse, the population of temperate climates of the north tend to be masculine and beautiful in contrast to those from intemperate zones (Gobineau 1915, I: 151). Yarico gives Inkle her voice and she remains voiceless.

When Inkle talks about Yarico, he describes her physical appearance, "how wild and beautiful! Sure there's magic in her shape" (1.1). She is also judged to be not so black as her country men or indeed as her chambermaid Wowski, who is "of rather darker sort" (1.1). In accordance with the patriarchal 
perception of the female, Yarico is but a body. In The Second Sex, Simone de Beauvoir asserts that a woman is perceived through the male perception and not through her independent self. She writes, "Man defines woman, not in herself, but in relation to himself ... she is nothing other than what man decides; she is thus called 'the sex' (2011, 25). Significantly, Inkle, the patriarchal male, perceives Yarico, the woman, as a body. Such an approach has further implications in Yarico's case as it is in complete harmony with Colman's colonial agenda of dehumanizing her. This does not mean that patriarchal perception of women as a body does not dehumanize them. Thus, the physical description shows Yarico as a patriarchal woman but not an indigenous one. She is removed from her indigenous context that considers women as sacred entities with a spiritual side.

To Colman, Yarico is not only a voiceless body but most importantly a rootless one. Gobineau asserts that the inhabitants of the tropics "are mere savages and have no history at all" (1915, I: 149). Significantly, there is a persistent reference to Yarico's weak attachment to her land. Inkle tells her "when an opportunity offers to return to my country, you shall be my companion" (1.1). Happy with such a prospect, she responds, "Oh, Wonder! I wish my Countrywomen cou'd see me" (1.1). With such a response Yarico emerges as a rootless character

who is eager to leave her land. This shows her to have no history and consequently no human dimension. She is dramatized with a simple, primitive, animal-like instinct who follows the male she finds physically attractive. At one point Inkle accuses her of being a "simple girl" and "unenlightened Indian" (3.1). Apparently, Yarico is not the only woman who has a weak connection to the land. This becomes more apparent when Yarico points out that the other women of her tribe will be jealous when she leaves the island with Inkle.

The fact that Colman chooses the indigenous females and not the males to be so eager to leave their island can be related to the 
colonizers' effort to belittle their role as representatives of the land. By showing that the women are not in the least connected to the land, it would be easier for the colonizers to claim it. Rebecca Tsosie remarks that native women understood their existence involves a "spiritual dimension and [is] related ... to their land" (31). Due to such factor Bonita Lawrence asserts that for the colonizers, "it is mandatory to disconnect the indigenous women from land and community" (2010, 3). Critics tend to explain Yarico's readiness to leave her island as a spontaneous act of love (Marsden 2014 118; Escott 2016, 103-5; Knapp 2012, 225). Colman's manipulation of Yarico's character, the indigenous women's sacred connection to the land, along with the colonizers' project of possessing new territories and enslaving the inhabitants, makes such sentimental reading rather unconvincing. Through Yarico's indifference toward her land and eagerness to abandon it with a total stranger, Colman tries to sever her sacred connection with the land. She reminds Inkle, "I gave up all for you - my friends - my country: all that was dear to me, ... All, all was left for you, and were it now to do again I'd cross the seas, and follow you all the world over" (3.1). In traditional native cultures, a woman's identity "was firmly rooted in her spirituality, extended family and tribe" (Tsosie 2010, 31). By insisting that she will give up everything to be with Inkle, Yarico adopts the task of denying her own identity.

To stress Yarico's lack of a human dimension, she is exploited on moral, physical and spiritual levels. This multileveled exploitation is used to sanctify the dominance of the colonizers, represented by Inkle, over the indigenous population and their land. When Inkle appears on the island, it is Yarico who protects him from being killed by the indigenous men. She tells him, "'tis I alone can save you; your death is certain without my assistance" (1.1). Apparently, Yarico has the power and the independence to take a decision and execute it without conferring with others. The audience receives hints that she is not of a low status. Inkle's servant judges her to be a lady of quality, he tells him, "This must be a lady of quality, by her staring" (1.1). Servants are keenly aware of social 
status; thus they possess an uncanny ability to identify people's status correctly. Later in the play, when Inkle tries to sell her into slavery, he informs the buyer that "she's of no common stamp" (3.1). Colman's sly remarks regarding Yarico's uncommon status indicate that although she may not be exactly like the rest of her people, it does not mean that she is the colonizers' equal or beyond enslavement. This is most obvious through the contradiction between her dramatization as voiceless and rootless and her decision to protect Inkle against all odds. It also betrays Colman's deliberate attempts to strip Yarico of her power as an indigenous entity while exploiting it at the same time. This shows that her decision to protect Inkle cannot be separated from her indigenous identity as the representative of earth. The decision to protect him means that she sanctifies him. He becomes the chosen one, the sacred entity that is to be protected at all costs. Besides protecting his life from physical harm, she nourishes him. She informs him, "I will bring you food by day" (1.1). She gives Inkle a second life which is in harmony with her indigenous role as a life keeper/giver. Through protecting and feeding him, Inkle experiences a rebirth. His rebirth with the help of Yarico, the life giver, is an element that stresses his transformation into a sacred body just like her.

Inkle's transformation into a sacred entity takes another dimension through his physical union with Yarico. By giving him the right to her body, she gives him the right to the land. Since indigenous women represent earth, colonizers find physical dominance essential to control the land (Anderson 2000, 57). Young writes that to eighteenth-century anthropologists such practice is not a sign of the indigenous women's power. Rather, it is a testimony of the active Aryans as the "pre-eminently male group" (1995, 109; Gobineau 1915, I: 30). Bryan Edwards confirms the physical attraction of white men to the black women in the Caribbean. He writes that free women "of colour... are universally maintained by white men of all ranks and conditions, as kept mistresses. The fact is too notorious to be concealed or controverted" (1801, 25). To Gobineau the European men's physical 
attraction to black women is a mark of power and superiority. To him, the physical experience is rooted in "the civilizing instincts of these chosen [Aryan] people" $(1915,149)$. Their civilizing instincts "were continuously forcing them to mix their blood with that of others" $(1915,149)$. Thus, the marriage of Inkle and Yarico at the end of the play does not indicate love but rather the complete control of the colonizers. Bonita Lawrence writes that white men, especially traders, resort to intermarriage into the indigenous societies to secure their claim to the land $(2003,8)$.

Colman's spiritual exploitation of Yarico can be perceived through the reaction she displays to her future as a slave. Surprisingly, Yarico faces Inkle's decision to sell her into slavery with complete passivity. Colman makes it clear that becoming a slave is not an issue for Yarico, who fails to defend her freedom. Her only concern is that she will be separated from Inkle. Desperate to be with him, she pleads,

Stay but a little, I shan't live long to be a burden to you

I'll obey this man, and undergo all hardships for your

Good; stay but to witness e'm ... I soon shall sink with grief

... hear me bless your name when I am dying. (2.1)

Yarico's words could have been worthy of a great heroic love story, had the context been different. However, Yarico emerges as a woman with an enslaved spirit. With such an attitude Colman shows that she has the heart and mind of a slave who does not want to be separated from her master. Since indigenous women with their spiritual powers are considered to be the link between the world of the spirits and that of the living, Yarico's full submission to Inkle can be perceived as the recognition of his mastery over her body and soul and consequently over the land. Young explains that during the eighteenth century, the idea of the white supremacy was prominent (1995, 35, 65,

108-9). In our context the non-white race is the inhabitants of the 
tropical island who emerge as the inferior race. Their men are black savages who deserve to be enslaved. This is indirectly endorsed by the indigenous female Yarico who recognizes Inkle, the white colonizer, as the master of her body and land.

\section{The Self: The colonizers from London to Barbados}

Having established the tropical environment and its inhabitants as the Other, the colonizers along with their habitat emerge as the Self. Their superiority as the Self is displayed though their temperate environmental space and civilized inhabitants. The colonizers' environment to be considered in this context is both London and Barbados. Geographically Barbados is a tropical space, yet it will be considered as an environmental Self. This is due to the fact that it had been an English colony since 1626.

London's temperate environment can be perceived through its urbane design and green parks. Inkle's servant, Trudge, complains, "what a fool was I to leave London for foreign parts!That ever I should leave Threadneedle-street, to thread an American forest, where a man's as soon lost as a needle in a bottle of hay" (1.1). By the end of the eighteenth century, London was a cosmopolitan city synonymous with urbanism. The Self represented by urbane London is marked with well-charted and named streets. This is in sharp contrast to the American thick forest that has no design or direction. London is not only an urban space, but also has its share of green areas. In an ironic tone, Medium contrasts St. James's Park with the American forest where Inkle is missing. Upon his return, Medium expresses his surprise,

One would think, by your confounded composure, that you

were walking in St. James's Park instead of an American forest, and that all the beasts were nothing but good 
company. The hollow

trees here, centry boxes, and the lions in 'em soldiers; the Jackalls, courtiers, the crocodiles, fine women; and the baboons, beaux. (1.1)

The sharp contrast between St. James's Park and the tropical forest is most telling. The English park is a place of serenity and beauty, unlike the tropical forest that gives a sense of urgency and doom. The other difference is the human inhabitants of the park. The park is full of the fashionable Londoners. During the eighteenth century, it was a fashionable place to walk, to see and be seen in. Thus, one can meet all the representatives of London society: soldiers, courtiers, aristocrats, fine women and beaux. This makes the park a social place where people meet and talk. Jerry White describes London's parks in which the smartest was St James's, behind the royal palace in Pall Mall. When Londoners talked of the "the Park" in the eighteenth century, this is generally what they meant. It was "famed wellnigh throughout the world," a German visitor recorded in 1710. All Londoners of the middling classes and above knew it and all visitors had to experience it $(2013,10)$.

Needless to say, St James's Park with its sophisticated, elegant Londoners is a far cry from the hostile and primitive American forest. The superiority of the colonizers' environment is stressed through the tropical Barbados. This seems odd since unlike London, Barbados has a tropical geographical location. Barbados is situated roughly at 13 degrees north of the earth's equatorial plane. However, Barbados is presented as a temperate environment. When Wowski lands in Barbados, Trudge asks her, "But how do you like this, Wows? Isn't it fine?" (3.1). To his questions, she responds, "Wonder" (3.1). Indeed, in the eighteenth century Barbados was a wondrous place from the colonial perspective. The once-dense tropical forest had been transformed into a temperate and agricultural space. The island was deforested and replaced by large plantation estates that cultivated sugar. Justin Roberts explains how sugar transformed 
Barbados. He writes that "A sugar revolution in the late 1640s transformed Barbados and it became by far the richest of the English colonies in the Americas - a position it held until the early eighteenth century" $(2013,10)$. Due to its sugar trade and prime location, Barbados by the end of the eighteenth century became a major port for the transatlantic slave trade. Understandably, with sugar and slave trade, wealthy Barbados was one of the most coveted jewels in the British crown well into the middle of the eighteenth century (Sheridan 2000, 124; Marshall and Brereton 2003, 545). Its port town, Bridgetown, was one of the three largest cities in English America. It was fashioned after the English cities, a factor that turned it into a "regional centre for English activity in settlement,... and commerce" (Marshall and Brereton 2003, 544).

By the time Colman stages his play, Barbados' natural environment is no longer ideal: "Deforestation and intensive cane agriculture caused the soil quality to decline and created ... fuel shortage ... To maximize their dwindling resources and remain competitive, eighteenth-century Barbadians were forced to hone their skills and innovate" (Roberts 2013, 10). For more than two hundred years the land suffered from continuous abuse. However, while trying to idealize the English colonizers, Colman fails to mention their destructive behavior towards the environment. Through Trudge, Colman criticizes the Indians for killing the forest's animals to decorate their houses. Trudge tells Inkle, "If we once get clear of the natives' houses, we have little to fear from the lions and leopards; for by the appearance of their parlours they seem to have kill'd all the wild beasts in the country" (1.1). The fact that Colman praises the sophisticated Barbados through the Indian Wowski is not innocent. He wants the natives to endorse the colonizers' civilization. By extension such endorsement is also a condemnation of their own culture and way of life.

According to the tropical discourse the transformation of Barbados from the intemperate and primitive environment to being 
temperate and civilized is a credit to the white colonizers. David Livingstone endorses the colonizers' monopoly to superiority. $\mathrm{He}$ writes, "civilization could only arrive and be sustained in the tropics through outsiders' energy and agency" (1991, 12). Those outside agents happened to be the white race, as Gobineau stresses, "All civilization derive from the white race...none can exist without its help" (1915, I: 210). Young explains that "racist assumptions remained fundamental to the knowledge of the West and to the western sense of self ... western culture has always been defined against the limits of the others" $(1995,93)$.

In harmony with the tropical discourse, the human inhabitants of the made-temperate environment of Barbados are all white. Upon her arrival to Barbados, Wowski remarks to Trudge that the population are "all white men like you" and "fine ladies" with "Face like snow" (3.1). Wowski is impressed by the way the English men are dressed. To that Trudge responds, "a young flashy Englishman will sometimes carry a whole fortune on his back" (2.1). It is interesting to note that Colman pays attention to the clothes. This is due to the fact that in eighteenth century England, clothes were a distinct mark of civilized and human identity (Wheeler 2000, 14-21). The English are dressed in expensive clothes and not almost naked like the indigenous inhabitants of the Caribbean. The colonizers have turned Barbados into a mini-London, where its original tropical primitiveness disappears. This might explain why Colman removes the thousands of black slaves from the Barbados scene; their physical presence in the dramatic Barbados would undermine his presentation of the Self as the civilizing agent.

Having established the English identity of the inhabitants of Barbados, Colman gives a more detailed picture of their qualities as civilized and benevolent agents. The civilized aspect is embodied by Inkle while the benevolent side is represented by Sir Christopher Curry, the governor of Barbados. Significantly, all aspiring empires, particularly the ancient Roman Empire to which Britain perceived itself as heir, depended upon two elements, 
territory expansions and moral values. To Rome these two elements were at the heart not only of its political system but above all its right to rule other nations (Lusnia 2006, 272-99). Through Colman's dramatization of the colonizers as the Self, he proves himself a faithful adherent to the Roman imperial concept.

Through his profession as a merchant, Inkle is dramatized as the civilizing agent of the British Empire. The connection between trade and civilization may not be clear without considering colonization. During the eighteenth century, it was believed that "colonization, commerce, and civility reinforced one another" (Greene 2013, 34). Malachy Postlethwayt, one of the British eighteenth century commercial experts, writes that the absence of colonization and commerce explains the savage and uncivilized "disposition" of "the wild ... American Indians" (1757, 257). Pointedly, the audience's first encounter with Inkle happens while he has been exploring the dangerous American forest. The terrified Trudge, Inkle's uncle's desperate servant, says

This is to have to do with a schemer! A fellow who risks his life for

a chance of advancing his interest. Always advantage in view, I trying, here to make discove-ries, that may promote his profit ... Nothing else could induce him to quit our foraging party from the ship. (1.1)

Critics tend to read Trudge's words as a testimony of his nephew's selfish and self-serving character. Jean Marsden believes that Inkle emerges as an unappealing character (2014, 693). She supports her conclusion with the fact that eighteenth-century actors and managers tried to rewrite his character and make him more sentimental and less calculating (2014, 693). However, his character is in harmony with what is expected from a merchant in eighteenth-century Britain. To Trudge's frustration, Inkle explains that his delay is due to his "Reflection" in the forest. When his uncle advises him to use his "Heels" instead of his "head" (1.1), Inkle 
responds

My heels! Here's pretty doctrine! Do you think I travel merely for motion?

... What, wou'd you have a man of business come abroad, scamper extravagantly ... then return home, and have nothing to tel. ... 'Sdeath, sir, would you have me travel like a lord? ...

Travelling, Uncle, was always intended for improvement; and improvement is an advantage; and advantage is profit, and profit is gain. (1.1)

He continues,

I have been comparing the land here, with that of our own country ... and calculating how much it might be made to produce by the acre ... I was thinking too if so many natives could be caught how much they might fetch at the West India Market. (1.1)

Inkle's commitment to his role as an English merchant is obvious through his bravery. Unlike his companions who are not merchants, he remains unfazed by the danger surrounding him. He remains focused and tries to turn the threats of death by the natives to his advantage. That is why he starts to think about turning the tropical forest into a cultivated land. Barbados is a good example, the colonizers cut down the forest and turned the land into plantations for sugar.

Inkle's insistence to assess the chance for profits and improvement is not simply an individual inclination, but a collective commercial attitude. English merchants were greatly 
respected in England for such attitudes. As a merchant, Inkle has a great chance of improving his profits. During the eighteenth century, which was also called the mercantile century, British merchants were highly appreciated. In 1760 the economist Adam Anderson writes, "To the instrumentality of Commerce alone, ... the Britannic Empire is most peculiarly indebted for its Opulence and Grandeur, its Improvements in Arts and Knowledge; and in general, for the great bulk of its solid Comforts and Conveniences" (1764, 1: 5). David Ormrod stresses that during the eighteenth century "trade ... came to occupy an unprecedented place in the national esteem" $(2005,1)$. He also explains that to many during the eighteenth century, commerce and expansion were "closely linked with growing sense of national identity and assertiveness" $(2005,3)$. This explains the dominant images of the merchants and their callings during the eighteenth century. Ormrod explains that the British merchant and his cargo was often depicted "at the heart of a prosperous and godly community ... attended by the muse of wisdom" $(2005,2-3)$.

The eighteenth century in particular witnessed what can be described as cut-throat commercial competition. The English merchants competed with the French, the Dutch and the Spanish. Frequently, these competitions took the form of bloody and expensive wars. Sir John Seeley asserted, "Trade led naturally to war, and war fostered trade throughout the [eighteenth] century" (Rees 1925, 130). To be ahead of the game, English merchants needed to be ruthless and competitive. To strengthen the merchants' competitive abilities and facilitate their trading missions, the British government implemented rules and planned wars (Satsuma 2013, 97-170,

222-43). Thus, Inkle's words about profits and exploitation, though not sentimental, are yet pragmatic and patriotic.

According to the tropical discourse, these trading missions are also civilizing enterprises. David Arnold writes that during the 
eighteenth century, it was believed that primitive communities needed the Europeans to civilize them $(2000,8)$. James Prichard identifies whiteness with civilization. He writes that "white skin, ... became both a marker of civilization and product of it" (Young 1995, 35). Inkle can be read as a marker of civilization when he rejects Yarico's advice. She urges him to "fly and seek the woods; ... there we'll wander hand in hand together ... No cares will vex us" (3.1). In response, Inkle marks the boundaries of civilization,

this is mere trifling of an unenlightened Indian. Hear me

Yarico; my countrymen and yours differ as much in minds as in complexions. We were not born to live in woods and caves -

to seek substance by pursuing beasts - We Christians, ... hunt

money ... But here, 'tis money which brings us ease, plenty, command, Power, everything, and of course happiness. (3.1)

Inkle is being vocal about the marks of civilization as seen by white males who belong to temperate environments, as opposed to a noncivilized tropical way of life. Inkle's ultimate role as a civilizing agent is to be perceived through removing Yarico from the tropical forest to the civilized Barbados and their marriage. Gobineau argues that the white race whom he also calls the "chosen people" have "civilizing instincts ... that were continuously forcing them to" improve the lives of the Other (1915, I:149). Inkle's decision to marry Yarico is the ultimate civilizing endeavor on Inkle's part. Once again, Gobineau blames the civilizing instincts of the white race. He believes that "mixture of blood ... are beneficial" to the savages as it will ennoble and raise them, however, to the white race it humiliates and debases their noble persons (1915, I: 210). The triangle of commerce, civilization and colonization could not be more obvious.

Sir Christopher Curry, who is also Barbados' governor, 
is the benevolent face of the empire. Significantly, he displays a highly moral nature in both the private and public domains. He is a kind and compassionate father figure to his daughter, Narcissa, who arrives from London to marry Inkle. As a public figure, he has the reputation of being just and vocal about injustices. As a kind father, he gives his daughter the permission to break her promise to marry the rich Inkle and forge a new understanding with the morally upright Captain Campley. The captain declares his affection to Narcissa,

I am a Soldier, Sir Christopher; Love and War, is the Soldier motto;

and tho' my income is trifling to your intended son-inlaw's,

still the chance of war has enabled me to support the object of my love above indigence. Her fortune, Sir

Christopher, I do not consider myself by any means entitled to. (3.1)

Impressed with his upright character and genuine love for his daughter, he responds,

...but you must tho', Give me your hand, my young Mars

and bless you both together. -

Thank you, thank you for cheating an old fool into giving his daughter to a lad of spirit. (3.1)

Indeed, his appreciation for the highly moral and spirited captain can be perceived as a nod of recognition to the British navy that played a key role in the colonization and expansion of the empire. Besides commerce, the navy was appreciated as "their progress was reported in numerous tracts and journals as indicator of national well-being and prosperity, and naval power was equated with 
national security" (Ormrod 2005, 1). The governor's appreciation of the captain is nowhere to be traced in his perception of Inkle, whom he finds morally wanting. Sir Christopher deemed his selfish and inhuman treatment of Yarico morally unacceptable. Upon learning of Inkle's desire to sell into slavery Yarico, who saved his life, he responds with indignation:

mean, sordid wretch! dead of all sense of honour, gratitude,

or humanity - I never heard of - such barbarity! ...

Come, come,

cheer up, my girl. You shan't want a friend to protect you,

I warrant you. (3.1)

Being a highly compassionate figure in both private and public domains shows Sir Christopher to be the perfect political representative of the British Empire. He is not in Barbados in his personal capacity but as a governor appointed by the British crown. Thus, his virtuous and just character is a reflection of the British Empire. Sir Christopher and the colonial system he represents have the moral sentiments and ability to correct inhuman behavior when needed. Thus, through the civilizing merchant, Inkle, and the benevolent politician, Sir Christopher Curry, the empire and its representatives emerge as the superior Self. As such they have the moral and political right to be entrusted to rule over the tropical Other.

\section{The empire and the dark face of slavery: Avoidance and denial}

To stress the positive image of the colonizers, the Self, Colman avoids honest discussion of Britain's key role in the transatlantic slave trade and distances the British from such a practice. Significantly, Colman omits not only England's role but most importantly that of Barbados. It is essential to stress that the British slave trade was an institutional practice and not an individual enterprise. This means that the slave trade was 
charted and regulated by the British crown and parliament from 1558 until the abolishing act in 1807 (Inikori 1992, 645). The eighteenth century was considered to be the "heyday of the British slave trade and a rapid upsurge in the number of enslaved Africans in North America and the Caribbean" (Morgan 2007, 12). It cannot be denied that the slave trade was one of Britain's most profitable and flourishing businesses (Meredith 2014, 191-4). By the time the play was staged, Barbados was one of the most profitable British settlements in the Caribbean due to the cultivation of sugar and the slave trade. Its geographic location facilitated its role as a center of re-exportation of slaves to other destinations and exportation of sugar to Europe and America. Such roles gave Barbados a political importance in the British Empire beyond its small size (Newman 2013, 54, 65). Working on sugar plantations necessitated a constant supply of workers. Between 1627 and 1807 tens of thousands of white slaves from Britain and hundreds of thousands of African slaves were shipped to Barbados against their will to work on the sugar plantations (Newman 2013, 68; Jordan and Welsh 2008, 191). Their journey to Barbados or the middle passage was a synonym for barbaric horrors. On the island slave life "was sustained by a campaign of violence and brutality" (Stuart 2013, 212).

To disconnect the English from the slave trade, Colman finds it necessary to manipulate the historical role of the planters and the governor of Barbados, Sir Christopher Curry. To that end, the planters emerge as helpless figures with vague identity who depend upon the slave trade for much-needed workers. Colman stages four planters who are given numbers rather than names. This technique is meant to avoid identifying them as English. Historically, all planters in Barbados were English, since the English crown claimed Barbados as a territory in 1626. The majority of the land was given to English planters for cultivation on behalf of the crown, while the rest was bought by individual adventurers who were seeking fortunes in the Caribbean (Sheridan 2000, 81-2; Newman 2013, 54). 
Before the arrival of African slaves, the slaves in Barbados were only white. The influential and powerful planters, along with their agents in England, "worked hard to secure state support for regular shipment of large numbers of unfree, bound laborers, and by the mid [seventeenth century] Barbados had the largest market in bound white laborers in English America" (Newman 2013, 71).

The majority of white slaves came from Catholic Ireland. The Irish who survived the uprising and wars with England were brutally treated and shipped to Barbados to work as slaves in the plantations (Newman 2013, 81). The rest were a mixture of convicted criminals, vagrants, whores, orphans, and the homeless and jobless (Newman 2013, 73-8). Government, merchant and civic authorities encouraged the shipment of enslaved white labor and undesirable citizens to Barbados (Newman 2013, 734). In Barbados, the planters "developed... [one] of the most oppressive forms of English labor" (Newman 2013, 54). When the third planter tells other planters that the recently arrived ship had "brought only madam Narcissa, our Governor's daughter, from England; with a parcel of lazy, idle, white folks about her" (2. 1), he fails to give a historically accurate picture of the white people who arrived in Barbados. By the time Colman staged his play, Barbados had a notorious reputation as a hellish place for white slaves and people refused to go there unless, like Narcissa, they lived there. Elite planters "perfected a violent and oppressive system of bound labor to power the plantations that generated such wealth for themselves and for the mother country" (Newman 2013, 55). Tens of thousands of white slaves from the British Isles worked on the island and "many died, under an unprecedentedly harsh regime ... [1] ong terms of service,... the local disease ... and brutal work" (Newman 2013, 55, 62).

Apart from being unidentified, the planters are dramatized as hopeless and helpless figures seeking capable black slaves. The fourth planter says "we want slaves ... give me a vessel ... all the lading tumbles out as black as my hat" (2.1). Colman allows his 
planters to emerge as powerless figures who live at the mercy of the slave suppliers. By doing that the planters give the message that they simply make use of an existing and independent system to cultivate their land. Colman misleads his audience and overlooks key historical factors that prove that the planters in Barbados were at the heart of the slave trade and not mere hapless clients. By the middle of the seventeenth century,

a planter class had already taken shape, with

a small and powerful group of great planters at its heart. ... The families of the great planters dominated the Governor's Council or sat in the Assembly, forming a cohesive and commanding ruling elite. By 1680 the highest political, military, and judicial offices were controlled by these elite planters ... [who] enjoyed nearly unrestrained political and judicial power on Barbados, and they shaped the island to suit their interests. (Newman 2013, 59)

Due to the planters' brutal and savage work regime the mortality rate among white slaves was high. To solve this problem of the work force, they bought African slaves who proved more physically disposed for hard work and the intemperate weather conditions (Newman 2013, 64, 68). Thus, the planters saw to it that Barbados became not only a final destination to African slaves but also a market for resale on to other destinations (Morgan 2007, 15).

To widen the distance between the British and the slave trade, Colman allows the Barbados governor, Sir Christopher Curry, to emerge as an anti-slavery figure. When Inkle offers him Yarico as a slave, he responds, "Though I witness this custom every day, I can't help thinking the only Excuse for buying our fellow-creatures, is to rescue 'em from the hands Of those who are unfeeling enough 
to bring 'em to market" (3.1). Sir Christopher Curry's words are highly ironical. He does not only deny their role in the slave trade, he insists that they buy slaves to offer them a better life. In addition, he allows slavery to emerge as an individual practice rather than an imperial policy. As a governor of a British colony, he is the one who supervises and regulates the rules that are implemented on his island. To insist that he has nothing to do with the practice of slavery except making it less damaging is historically inaccurate. It is essential to keep in mind that the governor's political position in British colonies "derived legal legitimacy from the Crown" (Steele 2001, 110). Technically, the governor is supposed to protect the interests of the Crown, which are connected to the colony. According to the practice of Governance during the eighteenth century,

the Governor or Lieutenant-Governor exercised executive, judicial, and legislative authority in each royal colony. The Governors represented a monarchical power ... the Governor not only exercised most of the functions of the Crown, but also some delegated functions of the Secretary of the State and the Treasury, as well as serving as Vice-Admiral and military Commander-in-Chief ... Governors called and dissolved the elected colonial assemblies and retained a veto over their legislations. The Governor also nominated members for the colonial Council.

(Steele 2001, 110)

The legal duties of the governor, along with his legislative and executive power, show that men like Sir Christopher Curry were completely responsible for what happened in their colony. Thus, Sir Christopher Curry as the governor of Barbados, as well as the 
planters, was completely accountable for slavery. They consolidated their power as planters and slave traders through reminding their government of their enormous contribution to the empire's economy and by extension its political supremacy. In response, parliament passed several Acts to protect and increase their power (Morgan 2007, 51-82). Practically, the entire system in Barbados could not operate without the African slave system. When Colman staged his play, $70 \%$ of the Barbados population were African slaves. Most of these slaves, along with the other ones in the Caribbean and North America, were transported from Africa in British ships (Morgan 2007, 14-15). Thus, it is no surprise that between 1750 and $1780,70 \%$ of the British government's income was connected to the slave trade and the colonies in the West Indies. ${ }^{2}$

To further cover up the grand economic and imperial agenda, along with the inhuman implication of slavery, Colman enlists Inkle's support. Inkle repeats Sir Christopher's words about enslaving free black people to improve their quality of life. To justify selling Yarico into slavery, Inkle explains his motivations: "I'm laboring for your good. My interest here is nothing. ... But see, my Yarico, ever anxious for your welfare, I've found a kind, good person, who will protect you" (3.1). Inkle's justification is in harmony with tropical theory that dramatizes the indigenous inhabitants as the inferior Other. Colman makes it clear that the English colonizers have the moral and intellectual superiority to improve the tropical environment and provide its inhuman inhabitants with a better life through depriving them of their freedom and making them their own slaves. Thus, enslaving them can be not only morally justified but acceptable.

\section{Conclusion}

Significantly, in an attempt to mask his promotion of slavery and imperialism, Colman follows the colonial policies that exploit others and insist on keeping the moral high ground. This perception challenges the dominant reading of Inkle and Yarico as an anti- 
slavery play. To mask his defense of slavery and colonization, Colman follows a complex and multifaceted dramatization. In an attempt to achieve his goal Colman follows three steps; dehumanizing the Indians, humanizing the English and denying them any key role in the slave trade while limiting their role to improving the existing bad situation. The dehumanization of the Indians and humanization of the English are manifested through a contrast between the natural environment and human inhabitants of the Caribbean island and England.

The theory of tropicality is the ppopiate critical tool to expose Colman's racial discourse, which perceives the natural environment of the tropics along with its inhabitants as the inferior Other. The natural environment of the island is described as dangerous, with its predators and thick forest. The black natives are no less dangerous. Their black skin is associated with savagery and cannibalism. Yarico, who has been romanticized and used by various critics to prove Colman's anti-slavery dramatization, shares the dehumanizing fate of her people. The theory of indigenous feminism helps to expose the romantic façade of Yarico and Inkle's love story. Colman's dramatization of Yarico is far more complex and subtle than that of the indigenous males. Yarico is dehumanized through two complex steps: she is denied cultural identity and then exploited. In indigenous culture women occupy a sacred place as life givers and representatives of the land. They are also considered to be the medium between the world of the spirits and its physical manifestation. None of these qualities are connected with Yarico who is dramatized as a voiceless and rootless body. Throughout the play, she is given one single mission and that is the adulation of the selfish English Colonizer, Inkle. Without roots or history, she emerges as nonhuman and savage. As such, she is exploited on moral, physical and spiritual levels. Her exploitation is designed to preserve Inkle's life and sanctify his presence, as the new master of her land and people. These acts are deeply connected to her indigenous sacred position as the life giver. By giving Inkle a second life she 
sanctifies him as the chosen one. Their physical union confirms Inkle's position as the master of her body/land. The fact that Yarico proves to be more concerned about being separated from Inkle than about becoming a slave confirms her slavish heart and his mastery. Beyond doubt Yarico endorses confirms Inkle's right to mastery not only over herself as an individual but over her land and people.

In sharp contrast to the inhuman inhabitants of the intemperate zone, the colonizers from the English temperate environment emerge human and civilized. Significantly, the colonizers' environment is not only the temperate and civilized London but Barbados as well, which geographically belongs to the tropical zone. Significantly, Colman shows how the English have tamed and civilized Barbados, making it temperate just like London. . Inkle, the merchant, stands as the civilizing agent. His individual moral short comings are buried under Yarico's infatuation and the political and commercial power of the growing British Empire. Inkle's role is in harmony with the eighteenth-century concept that connected commerce, colonization and civilization. Sir Christopher Curry is the human face of the British Empire, and this is clear through his public and private images. As the Governor of Barbados, Curry is a kind father to his daughter Narcissa. This paternal kindness is extended to embrace Yariko, the indigenous slave. His kindness towards Yarico is designed to o confirm the moral superiority of the colonizers and denies their key role in slave trade. Through Sir Christopher and the planters, Colman limits their roles to what is necessary for work and to moral obligations. The planters, whose identities are not clear, need the slaves to cultivate their plantations. The governor of Barbados insists that they buy slaves to offer them a better life. At no stage does Colman reference the key role Barbados played in both white and black slavery. Thus, the English colonizers emerge as the superior and civilized Self who have the cultural and moral justification to enslave the inhuman Other. What is ironical is that this is done in the name of humanity and civilization of the British Empire. Such sophisticated and complex manipulation of historical facts, 
along with dramatic personas, indicates a well thought out and deliberate promotion of slavery and colonization.

\section{Notes}

1 Kelly, Jason M. "Anti-slavery movement, Britain." The International Encyclopedia of Revolution and Protest, edited by Immanuel Ness, Blackwell Publishing, Blackwell Reference Online, 2009. www.revolutionprotestencyclopedia.com.proxy.ulib.uits.iu.edu/ subscriber/tocnode.html? sid=g9781405184649_yr2012_chunk_g9781405184649103>

2 "British Involvement in the Transatlantic Slave Trade." The Abolition Project, 2009. abolition.e2bn.org/slavery 45.html. 


\section{References}

Anderson, Adam. A Historical and Chronological Deduction of the Origin of Commerce, Vol.1. London, 1764.

Anderson, Kim. "Affirmations of an Indigenous Feminist." Indigenous Women and Feminism: Politics, Activism, Culture, edited by Cheryl Suzack, Shari M. Huhndorf, Jeanne Perreault and Jean Barman, UBC Press, 2011, pp.8191.

---. A Recognition of Being: Reconstructing Native Womanhood.

Sumach Press, 2000.

Arnold, David. "Illusionary Riches: Representation of the Tropical

World, 1840-1950." Singapore Journal of Tropical

Geography, vol. 21, no.1, 2000, pp. 8-18.

Beauvoir, Simone de. The Second Sex. Translated by Constance Borde and Shilla Malovany Chevallier, Vintage, 2011.

Bhattacharya, Nandini. "Family Jewels: George Colman's Inkle and Yarico and Connoisseurship." Eighteenth-Century Studies, vol. 34, no. 2, 2001, pp.207-26.

Brown, Randy. Slavery in the British Caribbean. Pennsylvania University Press, 2017.

Choudhury, Mita. "Colman's Inkle and Yarico: Four Critical Perspectives; The Paradox of Empire in Inkle and Yarico." The Oxford Handbook of the Georgian Theatre, 1737-1832, edited by Julia Swindells and David Francis Taylor, Oxford University Press, 2014, pp. 696-798.

Clarke, John Henrik. "Slave Revolts in the Caribbean Islands." Presence Africaine, vol. 84, 1972, pp. 117-30.

Clayton, Daniel and Gavin Bowd. "Geography, Tropicality and Postcolonialism: Anglophone and Francophone Readings of the Work of Pierre Gourou." L'Espace Geographique, vol. 35, 2006, pp. 208-21.

Colman, George. Inkle and Yarico. Dublin: Brett Smith, 1807. (All quotes are from this text).

De Oviedo, Gonzalo Fernandez. Natural History of the West Indies. University of North Carolina Press, 1959. 
Dobie, Madeleine. Trading Places: Colonization and Slavery in Eighteenth-Century French Culture. Cornell, 2010.

Driver, Felix and Luciana Martins. "Views and Visions of the Tropical World." Tropical Vision in an Age of Tropical Empire, edited by Felix Driver and Luciana Martins, Chicago University Press, 2005, pp. 3-22.

Edwards, Bryan. The History, Civil and Commercial, of the British Colonies in the West Indies. Vol. II. London, John Stockdale, 1801.

Escott, Angela. "Yarico." Restoration Eighteenth Century Theatre Research, vol. 31, no. 1, 2016, pp. 103-5.

Felsenstein, Frank. "Colman's Inkle and Yarico: Four Critical Perspectives; The Faces of Inkle and Yarico." The Oxford Handbook of the Georgian Theatre, 1737-1832, edited by Julia Swindells and David Francis Taylor, Oxford University Press, 2014, pp. 688-705.

---. English Trader and Indian Maid, Representing Gender, Race and Slavery in the New World: An Inkle and Yarico Reader. John Hopkins University Press, 1999.

---. "Inkle and Yarico." Inkle and Yarico, the Incas, Two Plays by John Thelwall, edited by F. Felsenstein and Michael Scrivener Madison, Fairleigh Dickinson University Press, 2006.

Gobineau, Arthur Comte. The Inequality of the Human Race. Vol 1. Translated by Adrian Collins, Heinemann, 1915.

Greenblatt, Stephen. Marvelous Possessions: The Wonders of the New World. Oxford University Press, 1991.

Greene, Jack. Evaluating Empire and Confronting Colonialism in Eighteenth-Century Britain. Cambridge University Press, 2013.

Higginson, Thomas Wentworth. Black Rebellion: Five Slaves Revolts. Cosimo Classics, 2005.

Huhndorf, Shari M. and Cheryl Suzack. "Indigenous Feminism: Theorizing the Issue." Indigenous Women and Feminism: 
Politics, Activism, Culture edited by Cheryl Suzack, Shari M. Huhndorf, Jeanne Perreault and Jean Barman, UBC, 2010, pp. 1-17.

Inchbald, Elizabeth. The British Theatre: Biographical and Critical Remarks by Mrs. Inchbald. Vol. XX. London, Longman, 1808.

Inikori, Joseph E. "The Volume of the British Slave Trade, 1655-1807." Cahiers d'Etudes Affricaines, vol. 32, no. 128, 1992, pp. 463-688.

Jordan, Don and Michael Welsh. White Cargo: The Forgotten History of Britain's White Slaves in America. New York University Press, 2008.

Kanakamedala, Prithi. "Staging Atlantic Slavery." The Oxford Handbook of the Georgian Theatre, 1737-1832, edited by Julia Swindells and David Francis Taylor, Oxford University Press, 2014, pp. 673-87.

Knapp, Adrian. "The Theatre Has Power - The Power to Move: Aspects of Social Change in George Colman's and Paul Leigh's Inkle and Yarico." Slavery: Histories, Fictions, Memory: 1760-2007, edited by Franca Dellarosa, Napoli, Liguori Editore, 2012, pp. 223-44.

Lawrence, Bonita. "Gender, Race, and the Regulation of Native Identity in Canada and the United States: An Overview." Hypatia, vol. 18, no. 2, 2003, pp. 3-31.

Ligon, Richard. A True and Exact History of the Island of Barbados. London, Humphrey Moseley, 1657.

Livingston, David. N. "The Moral Discourse of Climate: Historical Consideration of Race, Place and Virtue." Journal of Historical Geography, vol. 17, no. 4, 1991, pp. 413-34.

Long, Edward. History of Jamaica, Vol. II. London, Iowndes, 1774. Lowenthal, David and Marlyn J. Bowden, editors. Geographies of the Mind: Essays in Historical Geography in Honor of John Kirtland Wright. Oxford University Press, 1967.

Lusnia, Susann. "Battle Imagery and Politics on the Severan Arch in the Roman Forum." Representation of War in Ancient 
Rome, edited by Sheila Dilont and Katherine E. Welch, Cambridge University Press, 2006, pp. 272-99.

Mocquet, Jean. Travels and Voyages into Africa, Asia, America, the East and West Indies. Translated by Nathaniel Pullen, London, William Newton, 1696.

Marsden, Jean. “Colman's Inkle and Yarico: Four Critical Perspectives; The Problem with Inkle A Study in Performance." The Oxford Handbook of the Georgian Theatre, 1737-1832, edited by Julia Swindells and David Francis Taylor, Oxford University Press, 2014, pp. 692-696

---. Theatres of Feelings: Affect, Performance, and the EighteenthCentury Stage. Cambridge University Press, 2019.

Marshall, Woodville and B. Brereton. "Historiography of Barbados, the Windward Islands, Trinidad and Tobago, and Guyana." General History of the Caribbean, edited by B. W. Higman, Palgrave Macmillan, 2003.

Matthews, Gelien. Caribbean Slave Revolts and the British Abolitionist Movement. Louisiana State University Press, 2006.

Meredith, Martin. The Fortunes of Africa: A 5000 Year History of Wealth, Greed and Endeavor. Public Affairs, 2014.

Morgan, Kenneth. Slavery and the British Empire, from Africa to America. Oxford University Press, 2007.

Newman, Simon P. A New World of Labor: The Development of Plantation Slavery in the British Atlantic. University of Pennsylvania Press, 2013.

O'Quinn, Daniel. "Mercantile Deformities: George Colman's Inkle and Yarico and the Racialization of Class Relations." Theatre Journal, vol. 54, no. 3, 2002, pp. 389-409.

Ormrod, David. The Rise of Commercial Empires: England and the Netherlands in the Age of Mercantilism, 1650-1770. Cambridge University Press, 2005.

Postlethwayt, Malachy. Great Britain's True System. London, Peter Harrington, 1757. 
Rees, J. F. "The Phases of British Commercial Policy in the Eighteenth Century." Economica, vol. 14, pp. 130-50.

Roberts, Justin. Slavery and the Enlightenment in the British Atlantic, 1750-1807. Cambridge University Press, 2013.

Saidero, Deborah. "Violence against the Earth is Violence against Women: The Rape Theme in Women's Eco-Narratives." Le Simplegadi, vol. 15, no. 17, pp. 263-273, DOI: 10.17456/SIMPLE-72.

Sandiford, Keith. "Inkle and Yarico: The Construction of Alterity from History to Literature." New West Indian Guide, vol. 64, no. 3-4, pp. 115-25, DOI: doi.org/10.1163/13822373-90002019

Satsuma, Shinsuke. Britain and Colonial Maritime War in the Early Eighteenth Century: Silver, Sea Power and the Atlantic. The Boydell Press, 2013.

Sheridan, Richard B. Sugar and Slavery: An Economic History of the British West Indies, 1623-1775. Canoe Press, 2000.

Steele, Ian. K. "The Anointed, the Appointed and the Elected: Governance of the British Empire, 1689-1784." The Oxford History of the British Empire: Vol. II: The Eighteenth Century, edited by P.J. Marshall, Oxford University Press, 2001, pp. 103-25.

Steele, Richard. The Spectator no. 11, March 13, 1711. Richard Steele and Joseph Addison, The Spectator Vol. 1, edited by Henry Morley, London, Routledge, 1891. www.gutenberg.org/files/12030/12030h/SV1/Spectator1.html\#section 11.

Stuart, Andrea. Sugar in the Blood: A Family Story of Slavery and Empire. Alfred A. Knopf, 2013.

Tsosie, Rebecca. "Native Women and Leadership, An Ethics of Culture and Relationship." Indigenous Women and Feminism: Politics, Activism, Culture, edited by Cheryl Suzack, Shari M. Huhndorf, Jeanne Perreault and Jean Barman. UBC Press, 2010, pp. 29-42. 
Walvin, James. Crossing Africa, the Americas and the Atlantic Slave Trade. London, Reaktion, 2013.

Wheeler, Roxann. The Complexion of Race: Categories of Difference in Eighteenth-Century British Culture. Pennsylvania University Press, 2000.

White, Jerry. A Great Monstrous Thing: London in the Eighteenth Century. Harvard University Press, 2013.

Young, Robert. Colonial Desires: Hybridity in Theory, Culture and Race. Routledge, 1995. 